\title{
A New Attestation of Ardaya, the General of Babylonia under the Declining Seleucid Rule
}

\author{
Yasuyuki MiTSUMA*
}

\begin{abstract}
This paper introduces an unpublished cuneiform Akkadian (Late Babylonian) document on the clay tablet BM 35183 of the British Museum. This document is a part of an astronomical diary, and includes a long historical account. A part of it concerns Ardaya, "the general of Babylonia," i.e. the commander of the army in Babylonia, and sheds new light on the collapse of Seleucid rule of Babylonia in the late 140s B.C. The new document reports that someone "abandoned" Ardaya, probably at a point between his defeat by the Elamite king Kamniskires I and the appointments of the new "general above the four generals" (governorgeneral of the Upper Satrapies of the Seleucids; however, the office's jurisdiction seems to have been restricted to Babylonia under the Arsacids) and "the general of Babylonia" at the conquest of Babylonia by the Arsacids. Another part of the document increases our knowledge of the administration of Esagil in the late second century B.C. It mentions Bêllūmur with his title zazakku. A person Bēl-lūmur as the šatammu of Esagil is attested in two documents of the 120 s and the 110s B.C. If he is the same person as Bēl-lūmur mentioned in the new document, it shows his past office in the late 140s B.C. and indicates that a person once served as the zazakku could become the šatammu.
\end{abstract}

Keywords: Babylonian astronomical diaries, Seleucids, Arsacids, Elymais (Elam), Esagil

\section{Introduction}

This paper introduces an unpublished cuneiform Akkadian (Late Babylonian) document on the clay tablet BM 35183 of the British Museum. This document is a part of an astronomical diary, ${ }^{1}$ and includes a new attestation of Ardaya, "the general of Babylonia," i.e. the commander of the army in Babylonia in the Seleucid and the early Arsacid period, ${ }^{2}$ who first came to the modern world's attention through the astronomical diary $-144 .{ }^{3}$ We first clarify the situation of Babylonia in the late 140s B.C. leading to the collapse of Seleucid rule in this area, then show the text of BM 35183, and discuss some remarkable descriptions in the tablet, relating them to the information from other documents.

\footnotetext{
* Post-Doctoral Fellow, Graduate School of Arts and Sciences, the University of Tokyo Abbreviations in this article usually follow those used in Roth 2010. Special abbreviations are shown at the end of this paper.

For the astronomical diaries, see Sachs and Hunger 1988, 11-38 and Mitsuma 2015.

For the function of the office, see Mitsuma 2002, 46.

The notation "-n" in this paper indicates a text number of the diaries published by Sachs and Hunger $(1988,1989,1996)$ and Hunger and van der Spek (2006). For the convention used to indicate a part of a diary, see Sachs and Hunger 1988, 36-38.
} 


\section{Babylonia in the Late 140s B.C.}

\section{Elamite Invasion and the End of the Seleucid Rule}

Diary -144 covers the period from Ab to Kislīm of SE 167 (late July to late December, 145/144 B.C. according to the Babylonian calendar) ${ }^{4}$ and belongs to the group of standard diaries. ${ }^{5}$ The diary preserves some important historical records and sheds light on the process of decline of the Seleucid Dynasty in Babylonia (māt Akkadî). ${ }^{6}$ In the month Ulūl, Kamniskires I Nikephoros, the king of Elymais (Elam), and his troops departed their country. Their action is recorded in -144 'Obv. 18' as follows: LUGAL KUR ELAM.MA ${ }^{\text {ki }}$ EN ERÍN ${ }^{\text {meš }}$ MAH $^{\text {meš }}$ TA KUR-šú ú-[....], "The king of Elam with numerous troops [....] from his country [...],", A Babylonian response to this action in the month Tašrìt is described in -144 'Obv. 36'-37' as follows: ITI BI ina qí-[bi šá $\left.{ }^{\mathrm{m}} A\right] r$ -

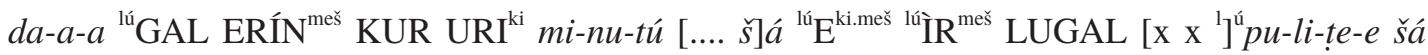
ina $\left.\mathrm{E}^{\mathrm{ki}} u^{\mathrm{u}}{ }^{\mathrm{ru}}\right] \mathrm{Se}$-lu-ki-'a-a i-man-nu-ú, "That month, at the com[mand of A]rdaya, the general of Babylonia, they counted the number [.... o]f the Babylonians, the servants of the king, [....] the (Greek) citizens who were in Babylon and Seleucia (on the Tigris)." This counting of the population was probably conducted for the purpose of mustering an army against the Elamite invasion. ${ }^{8}$ The targets of the counting include some population groups of Babylon and Seleucia on the Tigris. The latter is the Seleucid administrative center built in Babylonia. The (Greek) citizens (pulite or pulițānu) of Babylon are often attested in the diaries from SE 149 (163/162 B.C.) onward. ${ }^{9}$ They were introduced in the reign of Antiochus III (Boiy 2004, 207-208), or Antiochus IV (van der Spek 2009, 107-108), and separated from the traditional community of Babylon (the Babylonians). ${ }^{10}$ In Arahsamna, Ardaya, the one who ordered the counting, appeared at the Esagil temple in Babylon. He presented offerings to Bēl (Marduk), Bēltiya (Zarpanitu), and the "great gods" as follows (-144 Rev.' 17-19):

ITI BI U 4.12.KÁM ${ }^{\mathrm{m}} A r-d a-a-a{ }^{\text {lú }} \mathrm{GAL}$ ER[ÍN $\left.{ }^{\mathrm{mes}} \mathrm{KUR} \mathrm{URI}^{\mathrm{ki}}\right]\left\ulcorner\mathrm{x} \mathrm{x}^{\urcorner}[\right.$[... ina bi-rit mu-ter-tu 4 ] šá KÁ.DUMU.NUN.NA šá É-sag-gíl ${ }^{11} \mathrm{GU}_{4}$ u 5 SISKUR.SIS[KUR] ${ }^{\mathrm{mes}}$ ma-ru-tú ana ${ }^{\mathrm{d}} \mathrm{EN}$

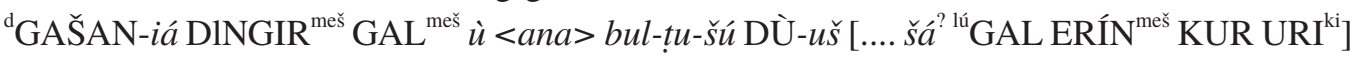

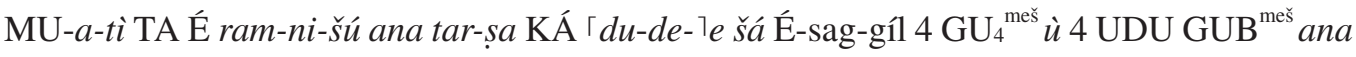
${ }^{\mathrm{d}} \mathrm{EN}{ }^{\mathrm{d}} \mathrm{GAŠSAN}-i a ́ r$ DINGIL $7\left[{ }^{\mathrm{meš}} \mathrm{GAL}^{\text {meš }} \ldots ..\right]$.

\footnotetext{
4 For the starting point of the Seleucid era according to the Babylonian calendar, 1 Nisān, 311 B.C., see Parker and Dubberstein 1956, 20.

5 The term "standard diaries" is used for the diaries, each tablet of which covers half a year, i.e. six months or seven months including an intercalary one, or a third of a year, i.e. four months or five months including an intercalary one, in this paper, following Mitsuma 2015, 53-54; cf. Hunger and Pingree 1999, 143. We find some tablets of diaries (such as -277A and -144), each of which covers five or seven months without an intercalary one (See Hunger and Pingree 1999, 143 for further references). We will also include those tablets into "standard diaries."

6 For the area denoted by the toponym māt Akkadî, see Zadok 1985, 223-226.

7 For the identification of this Elamite king with Kamniskires I and the interpretation of this passage, see Potts 2002, 350-351.

8 For the character of the counting, see Pirngruber 2012, 290.

9 -162 Rev. 11-12; -134B Obv.' 16-17; -90 'Obv. 30'-31'; et passim.

${ }^{10}$ For the character of these population groups, see Del Monte 1997, 38-39, 76-77, 86-87, 96-97; Boiy 2004, 194-209; van der Spek 2009.

${ }^{11}$ Offering presentations made ina bi-rit mu-ter-tu4 šá KÁ.DUMU.NUN.NA šá É-sag-gíl, "between the doors of "the Gate of the Son of the Prince' of Esagil"' are attested at -137D Rev.' 22-24 and 26-27.
} 
That month, the 12th, Ardaya, the gene[ral of Babylonia .... between the doors] of 'the Gate of the Son of the Prince' of Esagil he offered a bull and five fattened sheep to Bēl, Bēltiya, the great gods and <for> his life. [... of(?)] this [general of Babylonia] arranged four bulls and four sheep from his own property opposite the dudê gate of Esagil. [(He offered the animals)] to Bēl, Bēltiya, the [great] god[s ....].

In -144 Rev.' 20, we are informed of the departure of Ardaya from Babylon as follows: ${ }^{\text {lú } \mathrm{GAL}}$

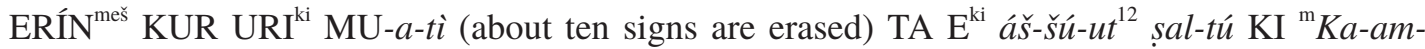
$m a-a ́ s ̌-k i-\left[i-r i^{13} \text { LUGAL KUR ELAM.MA }{ }^{\mathrm{k}}\right]^{\mathrm{i} ?}\left\lceil\mathrm{DUH}^{?}\right\urcorner^{14},{ }^{14}$ "This general of Babylonia departed (?) from Babylon for a battle with Kamniski[res, the king of Elam]." Ardaya was probably defeated by Kamniskires, because -144 Rev.' 21-22 records Kamniskires' victorious march in Babylonia as follows:

${ }^{\mathrm{m}} K a$-am-ma-áš-ki-i-ri LUGAL KUR ELAM.MA ${ }^{\mathrm{k}}\left[{ }^{\mathrm{i}}\right]$ ina $\mathrm{URU}^{\mathrm{mes}} u$ ÍD ${ }^{\mathrm{meš}} \check{s} a ́$ KUR URI ${ }^{\mathrm{ki}} \check{s} a l$ ta-niš GIN.GIN-ak x ḩu-ub-tú [.... M]U-a-tì i-hab-ba-t[u-ú-ma?] ši-lat-su-un i-šal-lal-lu-ú

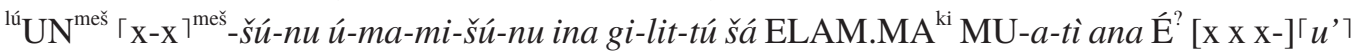
hat-tú u gi-lit-tú ina KUR [GÁL-ši ].

Kamniskires, the king of Elam, marched around victoriously among the cities and canals of Babylonia. They plundered this [.... and (?)] carried off their spoils. The people [....] their ...s and their animals for fear of this Elamite to the house (?) [There was] panic and fear in the land.

Although Kamniskires' attack constituted a serious threat to the Seleucid rule of Babylonia, he could not conquer the region. Some astronomical cuneiform tablets have date formulae of SE 168 (144/143 B.C.) and SE 169 (143/142 B.C.), and they are accompanied by the name of the Seleucid king, Demetrius II. ${ }^{15}$ Demetrius held Babylon at least until the end of SE $170(142 / 141$ B.C.) (Del Monte 1997, 243; cf. Boiy 2004, 167), because the diary -141F is dated with his name as follows ('Rev. 26'): na-șar šá TA KIN.2.KÁM EN TIL ŠE šá MU.1-me-1,10.KÁM ${ }^{\mathrm{m}}$ De-met-r $[i$ LUGAL ....], "Observation from the intercalary Ulūl to Addar of the year 170, Demetr[ius (was) king ....].",

Demetrius lost Babylon in the following year, SE 171 (141/140 B.C.). A diary of the year,

${ }^{12} a \check{s} \check{s} \bar{u} t$ or $a \check{s} \check{s} u t$ "concerning" is the preposition attested in some NB letters (ABL 848 Obv. 4; CT $545=$ SAA 18105 Rev. 4). The translation here, "for," is according to the context.

${ }^{13}$ The string of cuneiform signs for the name Kamniskires reminds us of the strange spelling of the same name, $k w m s ̌ k y r$, in the Parthian(?) legend on the small unit coins of Kamniskires-Orodes of Elymais (For the legend, see Haruta 1990, 460-463).

${ }^{14}$ The reading ELAM.MA $\left.{ }^{\mathrm{k}}\right]^{\mathrm{i} ?}\left\lceil\mathrm{DUH}^{?}\right\urcorner$ is based on the collation of the tablet (.... TA LUGAL ${ }^{\text {in }}$ in Sachs and Hunger 1996, 98.

15 Hunger 2006, No. 49 (LBAT 1267) Colophon 1-2 (SE 168); Hunger 2014, No. 168 (LBAT 1131+) 'Rev. 4' (SE 168); Rochberg 1998, Text 18 (LBAT 1467) Obv.1 (SE 169). These date formulae are shown with their transliterations by Del Monte (1997, 243) and Boiy $(2004,166)$.

${ }^{16}$ nașāru (̌̌a ginê), "(regular) observation" is the Akkadian term for the astronomical diaries (see Sachs and Hunger 1988, 11). 
-140A, consists of four monthly sections (one of the four is now completely lost) and covers the period from Nisān to Du'uz (early April to early August) of SE 171. The diary shows the name

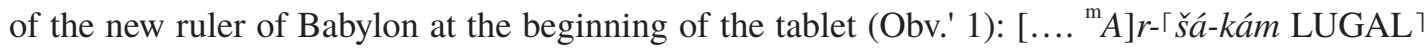

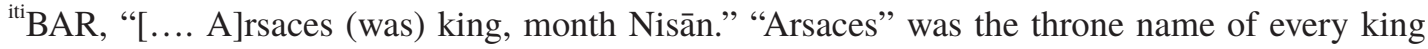
of the (Parthian) Arsacids (Strabo 15.1.36). The "Arsaces" of -140A indicates Mithridates I, who extended the Parthian Empire to the banks of the Euphrates (Just. Epit. 41.6.8). Boiy $(2004,167)$ argues that Mithridates conquered Babylonia before 1 Nisān, SE 171, and the date formulae of $-141 \mathrm{~F}$ ignores the change of the ruling dynasty from the Seleucids to the Arsacids in SE 170. Boiy's argument is based only on the date formula at -245B Lower Edge 1: na-șar šá gi-né-e šá TA BAR EN KIN ${ }^{\mathrm{m}} A n-t i-’ u$ - $k u$-su LUGAL TA IZI EN KIN ${ }^{\mathrm{m}} S e-\ulcorner l u-\urcorner k[u]\left\ulcorner\mathrm{A}-\check{s} \check{s}^{1} \mathrm{LUG}\left[\mathrm{AL}^{?}\right]\right.$, "(regular) observation from Nisan to Ulūl, Antiochus (was) king, from Ab to Ulūl, Seleucus, his son (was) king." According to Boiy $(2004,148)$, the scribe of -245B first attributed the six months from Nisan to Ulūl to the late king Antiochus II, ignoring the accession of the new king, Seleucus II, and then specified the reign of Seleucus in the months Ab and Ulūl at the end of the formula. We may also restore Mithridates's reign at the end of the date formula of -141F, if Boiy's argument is correct. However, it is unsafe to apply the practice attested only once to our case simply. More probable scenario is that Demetrius II held Babylon at the beginning of SE 171, but the scribe of -140A attributed the whole of SE 171 to the new king, Mithridates I. The scribe compiled the diary in the month Ab, SE 171, or later. At the time of the compilation, Babylon had already been under the influence of the new ruling dynasty, the Arsacids. He probably avoided showing the name of the eliminated ruler, Demetrius II on the tablet. A special attention to the conqueror of Babylon can also be found in -330, which records the battle of Gaugamela and Alexander III's entry into Babylon. Alexander is specially mentioned with the title "king of the world" in the diary ('Obv.' 15', 'Rev.' 11').

The Arsacid conquest of Babylonia seems to have occurred in Nisān, Ayar, or early Simān of SE 171 (van der Spek 2001, 450). Although the diary -140A records some historical events in the section on Nisān (Obv.' 20-23), they mainly concern the goddess Ištar of Babylon. The section on Ayar is now lost on the diary tablet. Eventually, the section on Simān records the introduction of the Arsacid era, which would be used side by side with the Seleucid era (Shahbazi 1986), as follows ('Rev. 3'): [....] GIN ${ }^{\text {meš }}\{\text { ina }\}^{\text {kušr }}$ GÍD.DA $^{\text {meš? } 7}$ [... MU.1-me-7.K]ÁM ${ }^{?}$ šá $\left\ulcorner\right.$ ši-i ${ }^{?}$ MU. $11-$

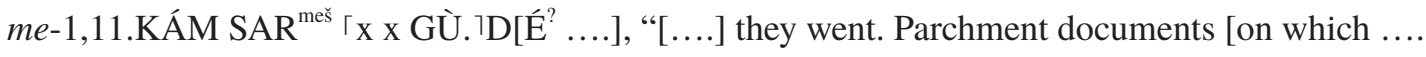
the year 107], which was the year 171, was written (lit. they wrote) .... were read [....]." ${ }^{, 17} \mathrm{AE} 1$ corresponds to SE 65 (247/246 B.C.). Therefore, SE 171 corresponds to AE 107.

The same diary, $-140 \mathrm{~A}$, inserts the throne name of Mithridates, Arsaces, at the beginning of the next section, i.e. the section for the month Du'uz, as follows ('Rev. 10'): [.... MU.]1-me-1,11. KÁM ${ }^{\mathrm{m}} A r$-šá-ka-a LUGAL ${ }^{\text {iti }}$ ŠU, “[.... the year] 171, Arsaces (was) king, the month Du'uz.” This insertion is irregular, because the year number and the ruler's name in standard diaries are usually indicated at the top, the bottom end, and the edges of their tablets. ${ }^{18}$ Therefore the normal monthly sections of the standard diaries, except for the first ones on the tablets, begin only with their month

\footnotetext{
${ }^{17}$ For this passage, see Sciandra 2012, 233.

${ }^{18}$ Top: -137E Obv.' 1; et passim. Bottom end: -141F 'Rev. 26'; et passim. Edges: -137D Lower Edge 1'; et passim.
} 
names. ${ }^{19}$ The irregular date formula at the beginning of the section for Du'uz (the fourth monthly section) of -140A should be inserted to express the debut of the Arsacids in Babylonia clearly (Oelsner 1975, 27-28). If this is correct, the Arsacid conquest could be dated to the previous month, Simān.

\section{Appointments of the New "General above the Four Generals" and "the General of Babylonia"}

We have not found any piece of historical accounts about Ardaya's fate after his defeat by Kamniskires. Instead, the section for the month Simān of -140A seems to record the announcement of the appointment of the new general in Babylonia by the Arsacids, as follows ('Rev. 5'-6'): ITI

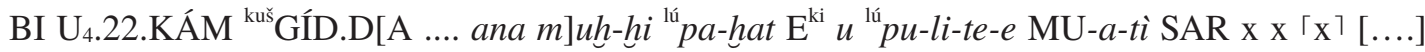

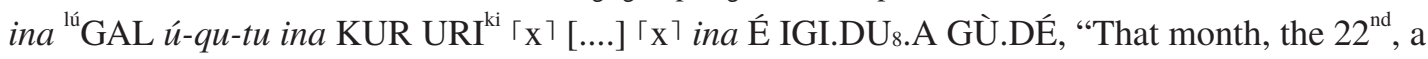
parchment document [....] written to the governor of Babylon and these citizens [....] to the office of the general in Babylonia [....] was read in the theatre., ${ }^{, 0}$ The general's name is Nikanor. Diary -140B mentions him and another general, Antiochus, ${ }^{21}$ as follows (Rev.' 9-10): ${ }^{\mathrm{m}} \mathrm{An}$-ti-'u-uk-s[u

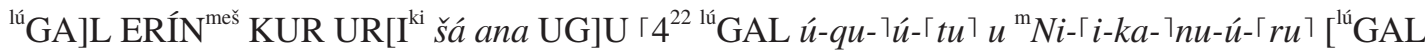
ERÍN $\left.^{\mathrm{m}}\right]^{\text {eš23 }}$ KUR URI $^{\mathrm{ki}}$, "Antiochus, [the gen]eral of Babylo[nia, who is abo]ve the four offices of generals, and Nikanor, [the gener]al of Babylonia." Diary -140A 'Rev. 8' reports Antiochus'

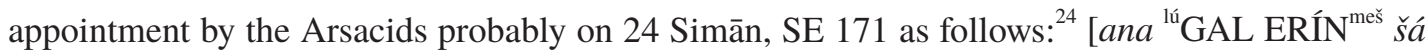

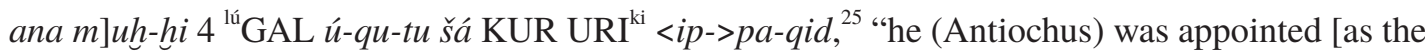
general who is a]bove the four offices of generals of Babylonia." Antiochus' appellations in -140A and B look like compositions of the official titles "general of Babylonia" and "general above the

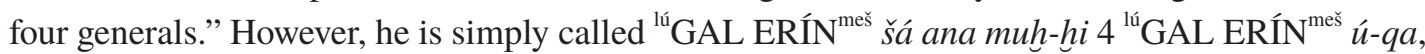
"the general above the four generals" in -140C Obv. 37, 'Rev. 31'.

The official title "general above the four generals" is probably an Akkadian translation of the Greek official title ho epi tōn anō satrapeiōn "one who is above the Upper Satrapies" (Mitsuma 2002, 42; 2007). ${ }^{26}$ The Greek title is attested in two Greek inscriptions published by Robert and reedited by Rougemont. ${ }^{27}$ The office was the governor-general of the Upper Satrapies, i.e. the satrapies east of the Euphrates under the Seleucids. ${ }^{28}$ Pirngruber criticized this identification for these three arguments: 1) The earliest attestation of "the general above the four generals" or similar titles appear at -229B 'Obv.' 9', but the crown prince Antiochus (later Antiochus I) was already appointed as "the one who is above the Upper Satrapies" in SE 18 (294/293 B.C.); 2) Molon was also a holder of this title under Antiochus III, but his authority did not extend to Mesopotamia and

\footnotetext{
${ }^{19}$-144 'Obv. 19', Rev.' 1, 23; -137D Rev.' 29; et passim.

${ }^{20}$ For the theatre of Babylon (É IGI.DU8.A, bìt tāmarti), see van der Spek 2001.

${ }^{21}$ For this person, see Monerie 2014, 128.

${ }^{22}$ The reading UG]U $\left\ulcorner 4\right.$ is based on the collation of the tablet $\left(\left[a^{?}\right]-n a^{?}\right.$ in Sachs and Hunger 1996, 140.

${ }^{23}$ Sachs and Hunger $(1996,140)$ also restores the lost signs as [ [" $\left.\mathrm{GAL}{ }^{?} \mathrm{ERÍN}\right]^{\text {meš }}$.

${ }^{24}$ The date and the name of Antiochus are recorded at 'Rev. 7'.

${ }^{25}$ The verb should be emended to its $\mathrm{N}$ preterite $3 \mathrm{cs}$ form, because it is used for describing the event at the specific point.

${ }^{26}$ For the title "general above the four generals," see also Potts 2007.

${ }^{27}$ Robert 1950, 73-75, pl. XXIII = Rougemont 2012, no. 67; Robert 1963, 76 = Rougemont 2012, no. 70.

${ }^{28}$ For the Euphrates as the western boundary of the Upper Satrapies, see Polybius 5.48.10-17; 1 Maccabees 3.37; Jerome, Commentariorum in Danielem 3.11.7-9.
} 


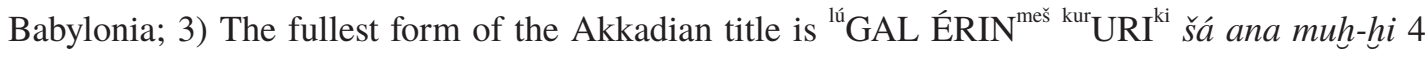

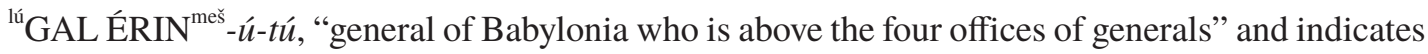
that the competences of the office were restricted to Babylonia from the beginning (Pirngruber 2012, 221). However, those three arguments seem not necessary to negate the identification of "the general above the four generals" with "the one who is above the Upper Satrapies." The crown prince Antiochus was not just the governor-general of the Upper Satrapies but the co-regent of his father Seleucus I and called "king" in Akkadian sources from 294/293 B.C. (Del Monte 1997, 226-227). ${ }^{29}$ Molon's authority seems to disagree with that of the "general above the four generals," who was generally stationed at Seleucia on the Tigris. ${ }^{30}$ However, we have no attestation of "the general above the four generals" in the early reign of Antiochus III and cannot know whether the authority of the office in those days was restricted or not. The composite appellations for the office in the Seleucid period ${ }^{31}$ seems not to be its title's fullest form but to indicate that a "general above the four generals" concurrently held the office of "the general of Babylonia."

However, the appellations for Antiochus in -140A and B require another interpretation, because he is mentioned together with Nikanor, "the general of Babylonia," in -140B. Those appellations for Antiochus might reflect the restriction of the jurisdiction of "the general above the four generals / one who is above the Upper Satrapies" into Babylonia in the Arsacid period. When the Arsacids occupied Babylonia, a province on the western boundary of the Upper Satrapies, and appointed their own "general above the four generals," Antiochus, his jurisdiction should have been restricted. If the general had the real power as the governor-general of the Upper Satrapies, his jurisdiction would cover whole realm of the Arsacids and his authority would exceed or parallel that of the king. Avoiding such a situation, the Arsacids might have restricted the jurisdiction of "the general above the four generals" into only one province, Babylonia. The composite appellations in the diaries from the Arsacid period may reflect such a change. ${ }^{32}$ If this is correct, we can think that Antiochus became "the general above the four generals" and Nikanor "the general of Babylonia" when the Arsacids occupied the region. Although both offices had their jurisdictions only over Babylonia, we can think that the former commanded the latter, judging from the original authority of "the general above the four generals" as the governor-general of the Upper Satrapies and the function of "the general of Babylonia" as the mere commander of the army in Babylonia.

Ardaya, the Seleucid general of Babylonia, may have kept his office until the appointment of the new general of Babylonia, Nikanor, under the Arsacids or lost his position at some point between his defeat by Kamniskires and the Arsacid conquest of Babylonia. The document of BM 35183 provides us with a missing piece of information about Ardaya's fate.

\footnotetext{
${ }^{29}$ Bengtson $(1944,407)$ lists Antiochus III (under his brother Seleucus III) and Antiochus, the eldest son of Antiochus III as the governor-general of the Upper Satrapies (Generalstatthalter des Ostens). However, we do not have any cuneiform source to know Antiochus III's status before his accession nor attestation of "general above the four generals" from the reign of Seleucus III. Antiochus, the son of Antiochus was appointed as the governor-general in the spring of 193 B.C. and died in Addar 193/192 B.C. (Mitsuma 2002, 52). He was called "king" when he held the office (Del Monte 1997, 236-237), and no "general above the four generals" is attested in cuneiform sources from his term of the office.

${ }^{30}$-178C 'Rev. 18'-22'; -140B Rev.' 9-11; -140C Obv. 37-38; -137C 'Rev. 16'; -134B 'Rev. 9'; -133B Rev.' 19-20; -124A 'Rev.' 19'; -119A2 'Obv.' 16'-17'.

31 Attested at -193B 'Obv.' 29'; -178C 'Rev. 18'; -152 'Rev.' 14'; -149B 'Rev. 11'.

32 Attested at -136B 'Obv.' 12'; -132B Rev. 21, 25; -124A 'Rev.' 19'.
} 


\section{The Text of BM 35183}

The tablet BM 35183 (Sp. 2 736) is now preserved in the British Museum. This small fragment measures $83.3 \times 71.7 \times 29$ millimetres. Cuneiform text is only preserved on one side. Since the side is flat, it is probably the obverse of the original tablet. When the author rotated the tablet upside down and observed the reverse, the side showed a layer of clay curving up toward the bottom and right ends. This means that we have the lower left part of the original tablet. In fact, the left edge of the preserved part shows the ends of some inner layers.

The text of BM 35183 shows a typical form of a monthly section of "standard" and "short" astronomical diaries. ${ }^{33}$ The arrangement of its entries is as follows:

Part 1: daily report of the sky,

Part 2: price list of six commodities (barley, dates, mustard, cress, sesame, and wool), ${ }^{34}$

Part 3: summary of the positions of the five visible planets,

Part 4: report of the level of the Euphrates, and

Part 5: account(s) of unusual historical event(s).

The text of BM 35183 has the same arrangement. 'Obv.' 2 ' shows the last part of a sky report. 'Obv.' 3 ' shows the end of a price list of the six commodities and the beginning of a planetary summary. 'Obv.' 4' shows a part of a report of the Euphrates' level. At last, a long historical account appears on 'Obv.'? 5'-14'. Although Ardaya, "the general of Babylonia," is mentioned in this part, the tablet BM 35183 cannot be joined to the tablet of -144 , which also shows some historical accounts about him. The latter tablet, BM $34609+34788+77617+78958$, has ample space for accepting some more fragments, because its upper half is completely lost. However, the sizes of the scripts and line spaces of these two tablets are different. BM 35183 puts four lines in a two-centimetres-high space, but BM 34609+ puts five lines in a space of the same height.

Following is the transliteration and English translation of the text of BM 35183 and comments on it. A copy of the tablet ('Obv.'? only) is shown in Figure 1.

BM 35183

'Obv.'?

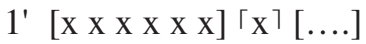

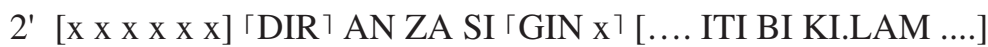

[....] clouds were in the sky. The north wind blew. [.... That month, the equivalent was: ....]

3' [x x x $a$-na 1] GÍN KÙ.BABBAR ep-šú i-nu-šú 「MÚL.BABBAR 7 [ina .... ITI BI ILLU ....]

[.... for one] shekel of wrought silver. At that time, Jupiter [was in .... That month, the river level ....]

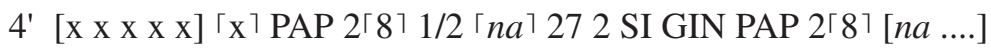

[....] total: twenty-eight and a half was the $n a$ (gauge). The $27^{\text {th }}$, it rose two fingers, total: twenty-eight was [the $n a$ (gauge).....]

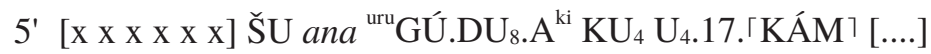

\footnotetext{
${ }^{33}$ For these groups, see Mitsuma 2015, 53-56.

${ }^{34}$ For the commodities mentioned in the list, see Slotsky 1997, 23-42.
} 
[.... entered Cutha. The $17^{\text {th }},[\ldots$.

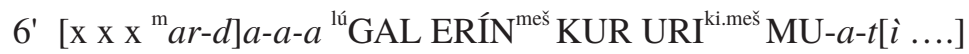

$[\ldots .$.$] this [Ard]aya, the general of Babylonia, [....]$

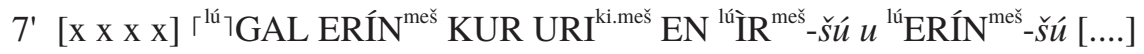

[....] the general of Babylonia with his servants and his troops [....]

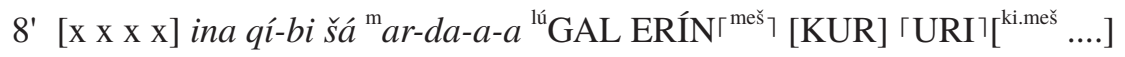

[....] at the command of Ardaya, the general of Babylonia, [....]

9' [x x x] 38 TA UD Ú DIŠ AMA TA UD $\left\ulcorner\mathrm{x}\right.$ x x ${ }^{7}\left[\ldots . .{ }^{\text {lú }} \mathrm{GAL}\right]$

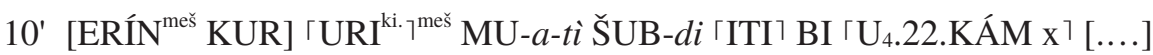

abandoned this [general of] Babylonia. That month, the $22^{\text {nd }},[\ldots .$.

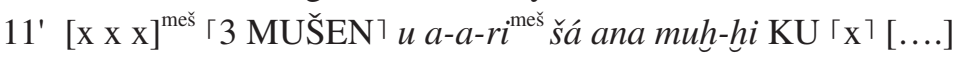

$[\ldots.] \mathrm{s}$, three birds, and rosettes which were toward [....]

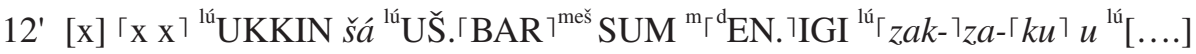

gave [....] to the council of weavers. Bēl-lūmur, the zazakku and [....]

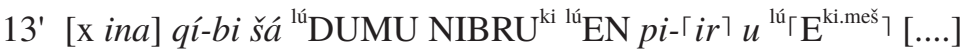

[.... at] the command of the son of Nippur, the overseer of a labor contingent, and the Babylonians [....]

14' $[\mathrm{x} \mathrm{x}]^{\mathrm{meš}}$ ana ${ }^{\mathrm{m} \Gamma \mathrm{d}}$ EN.IGI $\left.{ }^{1 \mathrm{k}} \mathrm{x}\right\urcorner[\mathrm{x}]\ulcorner\mathrm{x}\urcorner[\ldots$.

$[\ldots .$.$] s to Bēl-lūmur, the [\ldots .$.

Comments

2' For the phrase, DIR AN ZA “clouds were in the sky," see Sachs and Hunger $(1988,29)$.

ITI BI KI.LAM "That month, the equivalent was:" is the typical introductory phrase of the price lists of commodities in the diaries (-144 'Obv. 31'-32', Rev.' 15; -140C Obv. 30, 'Rev. 24'; et passim). Many of the price lists end with the phrase $a-n a 1$ GÍN KÙ.BABBAR ép-šú, "for one shekel of wrought silver" (-144 'Obv. 32'-33', Rev.' 16; -140A 'Rev. 20'; et passim) or its variant a-na 1 GÍN KÙ.BABBAR ep-šú (-153 'Rev.' 2'; et passim). This phrase is also attested at the beginning of line 3 '. This indicates that the original price list of BM 35183 begins from the right lacuna of line $2^{\prime}$ and the introductory phrase can be restored there.

3' The phrase ITI BI ILLU "That month, the river level” can be restored in the right lacuna of this line. This is the typical introductory phrase of the reports of the Euphrates' level in the diaries (-144 'Obv. 13', 33', Rev.' 17; -140A 'Rev. 21'; et passim). Line 4' shows a part of a river level report. Since the date "the $27^{\text {th, }}$ is mentioned there, the preserved part is very close to its end. Judging from the length of the left lacuna of line 4', the original report should begin from the right lacuna of line 3 '.

4' The first number $2\ulcorner 8\urcorner 1 / 2$ could also be read as $2\ulcorner 7\urcorner 1 / 2$, but $2\ulcorner 8\urcorner 1 / 2$ is better. This indicates a number of units on $\mathrm{na}$. $\mathrm{Na}$ was a kind of gauge on which the level of the Euphrates was read. The river level was measured from the assumed peak flood level downward. The unit used in connection with na equals four fingers (Sachs and Hunger 1988, 34-36; Brown $2002,40)$. The river level rose two fingers and reached twenty-eight on the $27^{\text {th }}$. Before that, 
the river level should have been twenty-eight and a half.

9' This line is left untranslated. Although the signs are well preserved in this line, it is very difficult to find any good syntactic relationship between them. If the number 38 is a (part of a) year number, it should be followed by the sign KÁM.

11 ' The numeral " 3 " is only preserved in its upper half. However, the sign should not be " 4 ," "5," or "6." Lower vertical strokes of those signs should appear just below the beginnings of their upper ones (see the signs A on this line and NÍG on the next line as examples of the similar composition of strokes).

Since the sign MUŠEN clearly has two, not three, vertical strokes, it can clearly be differentiated from RI. MUŠEN can represent plural "birds" by itself (see $C A D$, s.v. "ișṣūru;" 6 MUŠEN “six birds" appear at BE 6/1 118: 1).

$A-a-r i^{\text {meš }}$ can be interpreted as "rosettes" or "donkey foals." Although the latter seems to be more appropriate to the context, in which three birds are also mentioned, hāru (ha'aru, ajaru) "donkey foal" is a West Semitic loanword only attested in Mari (CAD, s.v. "hāaru"). If the birds are mentioned with rosettes, they seem not to have been real ones, but figures of birds decorating something together with the rosettes. An MB catalogue of jewels in a Nippur gold treasure records 1 e-rum KÙ.GI ša har-ba-qa-ni ù $a$-a-ra-ni NA N.ZÚ N[A $_{4}$ ....], "one golden staff (decorated) with a harbaqānu-bird and rosettes of obsidian and ... stone" (PBS 13 80: 5).

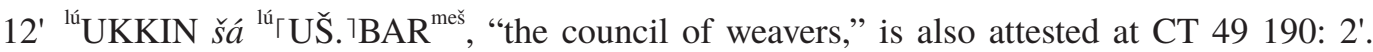
If line 11' and the left half of line 12 ' belong to the same sentence, it may report that the decorated object was given to the council.

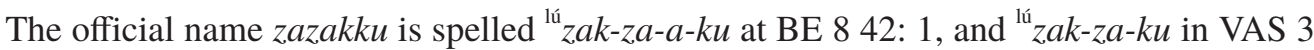
35: 5. For these spellings, see $C A D$, s.v. "zazakku."

The historical account of BM 35183 seems to begin with someone's or some group's entrance into Cutha and the date designation "the $17^{\text {th }}$ ('Obv.'? 5'). The next line ('Obv.'"6') shows the name and the title of Ardaya, "the general of Babylonia," for the first time on the fragment. 'Obv." 7' shows that Ardaya was accompanied by "his servants and his troops." 'Obv." 8' reports some action by Ardaya's command. However, 'Obv." 10' seems to report that someone "abandoned" him. If this incident is interpreted as one step of Ardaya's downfall, which was caused by his defeat in the war with Kamniskires in Arahsamna SE 167, or the conquest of Babylonia by Mithridates at some time in the first three months of SE 171, the monthly section of BM 35183 can be dated between Arahsamna SE 167 and the beginning of SE 171. We cannot date the section to Du' uz SE 171 or later, because the new general of Babylonia, Nikanor, was appointed in Simān.

'Obv.'" 12' shows that something was given to "the council of weavers," 35 and mentions Bēllūmur with his title zazakku in an unusual spelling. The official zazakku was the overseer of temple affairs for Babylonia (Beaulieu 1991, 103; Dandamayev 1994), or the special secretary of the king of the Neo-Babylonian Empire (Joannès 1994), especially in the reign of Nabonidus (555/554$539 / 538$ B.C.). The official called zazakku was also attested at the top of the temple Esagil in the

\footnotetext{
${ }^{35}$ For the professional kiništus in Hellenistic Babylon, see Boiy 2004, 202.
} 
Seleucid period. Three diaries of SE 143 (169/168 B.C.) contain an identical historical account about a zazakku, who was appointed by the king (-168A 'Rev. 12'-13'; -168B 'Rev.' 12'; -168C 'Rev. $\left.4^{\prime}-5^{\prime}\right)$. He was a jeweler, a brother of the šatammu of Esagil, i.e. the chief administrator and high priest of the temple, ${ }^{36}$ and his representative. A diary of SE 148 (164/163 B.C.), $-163 \mathrm{C}_{2}$, attests a zazakku official, who was also the representative of the šatammu of Esagil (-163C 2 Rev.' 17). This zazakku was probably the same person as the zazakku of $-168 \mathrm{~A} / \mathrm{B} / \mathrm{C}$ (Boiy 2004, 200). The same zazakku may be attested in the chronicle BCHP 15, which could be dated to SE 150 (162/161 B.C.) or SE 151 (161/160 B.C.) (Spek n.d.). The main part of this chronicle describes the theft of the gold, which was given to the temple council (kiništu) of Esagil, ${ }^{37}$ and the trial for the theft. The gold was given by a dignitary serving "the general of Babylonia" (BCHP 15 Obv. 2-3). Before the trial for the theft was held, the gold was measured at the command of the dignitary, a trustee (bèl piqitti) of the zazakku, and the temple council (BCHP 15 Obv. 7-12). This action and the zazakku's position at the top of Esagil attested in $-168 \mathrm{~A} / \mathrm{B} / \mathrm{C}$ and $-163 \mathrm{C}_{2}$ suggest that the zazakku in the Seleucid period was the overseer of temple affairs, although the jurisdiction of the office might have been restricted within Esagil. The zazakku was a royal official, because the jeweler of $-168 \mathrm{~A} / \mathrm{B} / \mathrm{C}$ was appointed to the office by the king. However, he (and the zazakku of $-163 \mathrm{C}_{2}$ ) was also the representative of the šatammu of Esagil. This indicates that the person in the office of zazakku could also be a part of the bureaucratic structure of Esagil. A person Bēl-lūmur as the šatammu of Esagil is attested in two documents of the 120 s and the 110s B.C. (BOR 4, 132: 7, 17; $-119 B_{1}$ 'Obv.' 11') and an undated document (CT 49 149: 2). ${ }^{38}$ If he is the same person as Bēl-lūmur mentioned in BM 35183, and if the aforementioned dating of the document on the tablet is correct, the document shows his past office in the late 140s B.C. and indicates that a person once served as the zazakku could become the šatammu.

'Obv.' 13' shows a command by a son of Nippur, who was the overseer of a labor contingent, and "the Babylonians." The diary $-141 \mathrm{C}$ also records another command by a son of Nippur, as follows ('Obv.' 11'): [....] U U.17.KÁM ina qí-bi šá 1-en líDUMU 「NIBRU ${ }^{\mathrm{ki}} 7$ šá ú-še-piš ku-um ${ }^{\mathrm{md}}$ MAŠ $.[\ldots .],.{ }^{39}$ " $[\ldots .$.$] The 17^{\text {th }}$, at the command of the son of Nippur, who acted for Ninurta-[...]." This Nippurean was probably the same person as the overseer mentioned in BM 35183, a diary which can also be dated to the late 140s B.C. If this identification is correct, we may consider Ninurta-[....] as the šatammu of Esagil and that the Nippurean acted for the šatammu. The Nippurean is mentioned together with ${ }^{\text {lú }} \mathrm{E}^{\text {ki.meš }} 7$, "the Babylonians" in BM 35183 'Obv.' 13'. The šatammu of Esagil and "the Babylonians of the kiništu of Esagil" are often mentioned together in the diaries, ${ }^{40}$ and the words "the Babylonians of the kiništu of Esagil" are sometimes abbreviated to "the Babylonians." 41 "The Babylonians" of 'Obv." 13' seems to be an abbreviation of the same kind. It is also possible that the words "UKKUIN šá É-sag-gíl, "of the kiništu of Esagil” are restored in the right lacuna of the line. If "the Babylonians" of BM 35183 are the members of the kiništu,

\footnotetext{
${ }_{36}$ For the character of the šatammu, see van der Spek 2000, 437; Boiy 2004, 196-197.

${ }^{37}$ For the temple council, see Boiy 2004, 202-204.

${ }^{38}$ van der Spek $(1986,60)$ once dated CT 49149 to SE 214 (98/97 B.C.), but the dating is not retained by van der Spek (2000, 440).

${ }^{39}$ The signs ${ }^{\text {md }}$ MAŠ can be seen on the copy (Sachs and Hunger 1996, pl. 193; $\ulcorner\mathrm{X}\urcorner$ in Sachs and Hunger 1996, 118).

${ }^{40}$ See e.g. -245B 'Obv. 4', -187A 'Rev. 8', -77A 'Obv. 27'.

${ }^{41}$ See e.g. -178C 'Rev. 19'; -93A Rev.' 25.
} 
the Nippurean accompanied by them acted for the šatammu of Esagil. The šatammu's name is unclear in BM 35183, but we can surmise that Ninurta-[....] of -141C was the šatammu, because he was also represented by the Nippurean. ${ }^{42}$

\section{Concluding Remarks}

Although it is a small fragment, BM 35183 gives us some useful pieces of historical information. It shows that someone abandoned Ardaya, "the general of Babylonia," probably at a point between his defeat by Kamniskires I in SE 167 and the appointments of the new "general above the four generals" and "the general of Babylonia" in SE 171 at the conquest of Babylonia by the Arsacids. The persons who served as those generals are as follows:

General above the four generals

SE 167

SE 171
?

Antiochus
General of Babylonia

Ardaya

Nikanor

Another part of BM 35183 mentions Bēl-lūmur with his title zazakku. He can be identified with Bēl-lūmur, the šatammu of Esagil in the 120s and the 110s B.C. If this is correct, the same person who served as the zazakku in the late 140s B.C. became the šatammu, as follows.

Bēl-lūmur in the late 140s B.C. zazakku

The same person in the 120s and the 110s B.C. šatammu of Esagil

BM 35183 sheds new light on the collapse of Seleucid rule of Babylonia and increases our knowledge of the administration of Esagil in the late second century B.C. Unfortunately, the preserved part of the tablet is still just a fragment. We hope we will find the fragment(s) joined to BM 35183, complement the text of the new diary, and improve its understanding.

\section{Acknowledgments}

My thanks go to the Trustees of the British Museum for allowing me to study the tablets BM $34609+34788+77617+78958$ (astronomical diary -144), BM $35053+35815$ (astronomical diary -140B), BM 35183, BM $45703+45741+45748$ (astronomical diary -140A) and to publish BM 35183. I also thank Christopher B. F. Walker for putting his provisional database of the tablets with astronomical and astrological contents of the British Museum Babylon Collection at my disposal, Stefan Zawadzki and Radosław Tarasewicz for their suggestions in reading the text on BM 35183, Reinhard Pirngruber for reading a manuscript of this paper and giving me useful comments. My thanks also go to Editage (www.editage.jp) for English language editing. All the remaining errors are, of course, mine. My research for this paper is funded by JSPS KAKENHI Grant No. 17H04527 and 26870111.

\footnotetext{
Abbreviations

AE Arsacid era

BCHP I. L. Finkel and R. J. van der Spek, Babylonian Chronicles of the Hellenistic Period, scholarly ed., Livius.org. http://www.livius.org/sources/about/mesopotamian-chronicles/ (accessed August 19, 2016).

Just. Epit. Marcus Junianus Justinus, Trogi Pompei Historiarum Philippicarum epitoma

SE Seleucid era

${ }^{42}$ The holder of the šatammu in the late 140s B.C. is not known. For lists of the already known šatammus, see van der Spek 2000, 438-440; Boiy 2004, 199.
} 


\section{Bibliography}

Beaulieu, P.-A. 1991: “UBARA (EZENxKASKAL) ${ }^{\text {ki }}=$ Udannu,” Acta Sumerologica 13, 97-109.

Bengtson, H. 1944: Die Strategie in der hellenistischen Zeit, vol. 2, Munich.

Boiy, T. 2004: Late Achaemenid and Hellenistic Babylon, Louvain.

Brown, D. 2002: "The Level of the Euphrates," in C. Wunsch (ed.), Mining the Archives: Festschrift for Christopher Walker on the Occasion of His $60^{\text {th }}$ Birthday, 4 October 2002, Dresden, 37-56.

Dandamayev, M. A. 1994: “The Neo-Babylonian zazakku,” Altorientalische Forschungen 21, 34-40.

Del Monte, G. F. 1997: Testi dalla Babilonia ellenistica, vol. 1, Testi cronografici, Pisa.

Haruta, S. 1990: "Kingdom of Elymais in the First and Second Centuries A.D.," Shirin (Journal of History) 73, 443-464 (in Japanese).

Hunger, H. 2006: Astronomical Diaries and Related Texts from Babylonia, vol. 6, Vienna.

Hunger, H. 2014: Astronomical Diaries and Related Texts from Babylonia, vol. 7, Vienna.

Hunger, H., and D. Pingree 1999: Astral Sciences in Mesopotamia, Leiden.

Hunger, H., and R. J. van der Spek 2006: “An Astronomical Diary Concerning Artaxerxes II (Year 42 = 363-2 BC): Military Operations in Babylonia," Arta, no. 002 (2006), 1-16.

Joannès, F. 1994: “À propos du zazakku à l'époque néo-babylonienne,” Nouvelles assyriologiques brèves et utilitaires 1994, 93-94 (no.103).

Mitsuma, Y. 2002: “Offices of Generals in Seleucid and Aršakid Babylonia,” Bulletin of the Society for Near Eastern Studies in Japan 45/2, 26-55 (in Japanese with English abstract).

Mitsuma, Y. 2007: “'The General in Charge of the Four stratēgiai'?” Nouvelles assyriologiques brèves et utilitaires 2007, 9-10 (no.09).

Mitsuma, Y. 2015: "From Preliminary Diaries to Short Diaries: The First and Second Steps in the Compilation Process of the Late Babylonian Astronomical Diaries,' SCIAMVS: Sources and Commentaries in the Exact Sciences 16, 53-73.

Monerie, J. 2014: D’Alexandre à Zoilos: Dictionnaire prosopographique des porteurs de nom grec dans les sources cunéiformes, Stuttgart.

Oelsner, J. 1975: "Randbemerkungen zur arsakidischen Geschichte anhand von babylonischen Keilschrifttexten," Altorientalische Forschungen 3, 25-45.

Parker, R. A., and W. H. Dubberstein 1956: Babylonian Chronology: 626 B.C.-A.D. 75, Providence, RI.

Pirngruber, R. 2012: “The Impact of Empire on Market Prices in Babylon in the Late Achaemenid and Seleucid Periods, ca. 400-140 B.C," Ph.D. dissertation, Vrije Universiteit Amsterdam.

Potts, D. T. 2002: "Five Episodes in the History of Elymais, 145-124 B.C.: New Data from the Astronomical Diaries," in P. Huyse (ed.), Iran: Questions et connaissances, vol. 1, La période ancienne, Paris, 349-362.

Potts, D. T. 2007: “Once More on 'the General Who Is above the Four Generals' and His Congeners," Nouvelles assyriologiques brèves et utilitaires 2007, 63-65 (no.51).

Robert, L. 1950: Hellenica: Recueil d'épigraphie, de numismatique et d'antiquités grecques, vol. 8, Paris.

Robert, L. 1963: "Review of Samothrace, vol. 2 part 1, The Inscriptions on Stone, by P. M. Fraser,” Gnomon 35, 50-79.

Rochberg, F. 1998: Babylonian Horoscopes, Philadelphia, PA.

Roth, M. T. (ed.) 2010: The Assyrian Dictionary of the Oriental Institute of the University of Chicago, vol. 20, $U$ and $W$, Chicago, IL.

Rougemont, G. 2012: Inscriptions grecques d'Iran et d'Asie centrale, London.

Sachs, A. J., and H. Hunger 1988: Astronomical Diaries and Related Texts from Babylonia, vol. 1, Vienna.

Sachs, A. J., and H. Hunger 1989: Astronomical Diaries and Related Texts from Babylonia, vol. 2, Vienna.

Sachs, A. J., and H. Hunger 1996: Astronomical Diaries and Related Texts from Babylonia, vol. 3, Vienna.

Sciandra, R. 2012: "The Babylonian Correspondence of the Seleucid and Arsacid Dynasties: New Insights into the Relations between Court and City during the Late Babylonian Period," in G. Wilhelm (ed.), Organization, Representation, and Symbols of Power in the Ancient Near East, Winona Lake, IN, 225-248.

Shahbazi, A. Sh. 1986: “ARSACIDS v. The 'Arsacid' era,” in E. Yarshater (ed.), Encyclopaedia Iranica, vol. 2, New York, 541-542. http://www.iranicaonline.org/articles/arsacids-v (accessed December 8, 2017).

Slotsky, A. L. 1997: The Bourse of Babylon: Market Quotations in the Astronomical Diaries of Babylonia, Bethesda, MD. Spek, R. J. van der 1986: Grondbezit in het seleucidische Rijk, Amsterdam. 
Spek, R. J. van der 2000: "The Šatammus of Esagila in the Seleucid and Arsacid Periods," in J. Marzahn, and H. Neumann (eds.), Assyriologica et semitica: Festschrift für Joachim Oelsner anläßlich seines 65. Geburtstages am 18. Februar 1997, Münster, 437-446.

Spek, R. J. van der 2001: “The Theatre of Babylon in Cuneiform," in W. H. van Soldt (ed.), Veenhof Anniversary Volume: Studies Presented to Klaas R. Veenhof on the Occasion of His Sixty-fifth Birthday, Leiden, 445-456.

Spek, R. J. van der 2009: "Multi-ethnicity and Ethnic Segregation in Hellenistic Babylon," in T. Derks, and N. Roymans (eds.), Ethnic Constructs in Antiquity, Amsterdam, 101-115.

Spek, R. J. van der n.d.: "Commentary on Gold Theft Chronicle (BCHP 15)."

http://www.livius.org/cg-cm/chronicles/bchp-gold/theft_2.html\#General (accessed September 1, 2016).

Zadok, R. 1985: Geographical Names According to New-and Late-Babylonian Texts, Wiesbaden. 


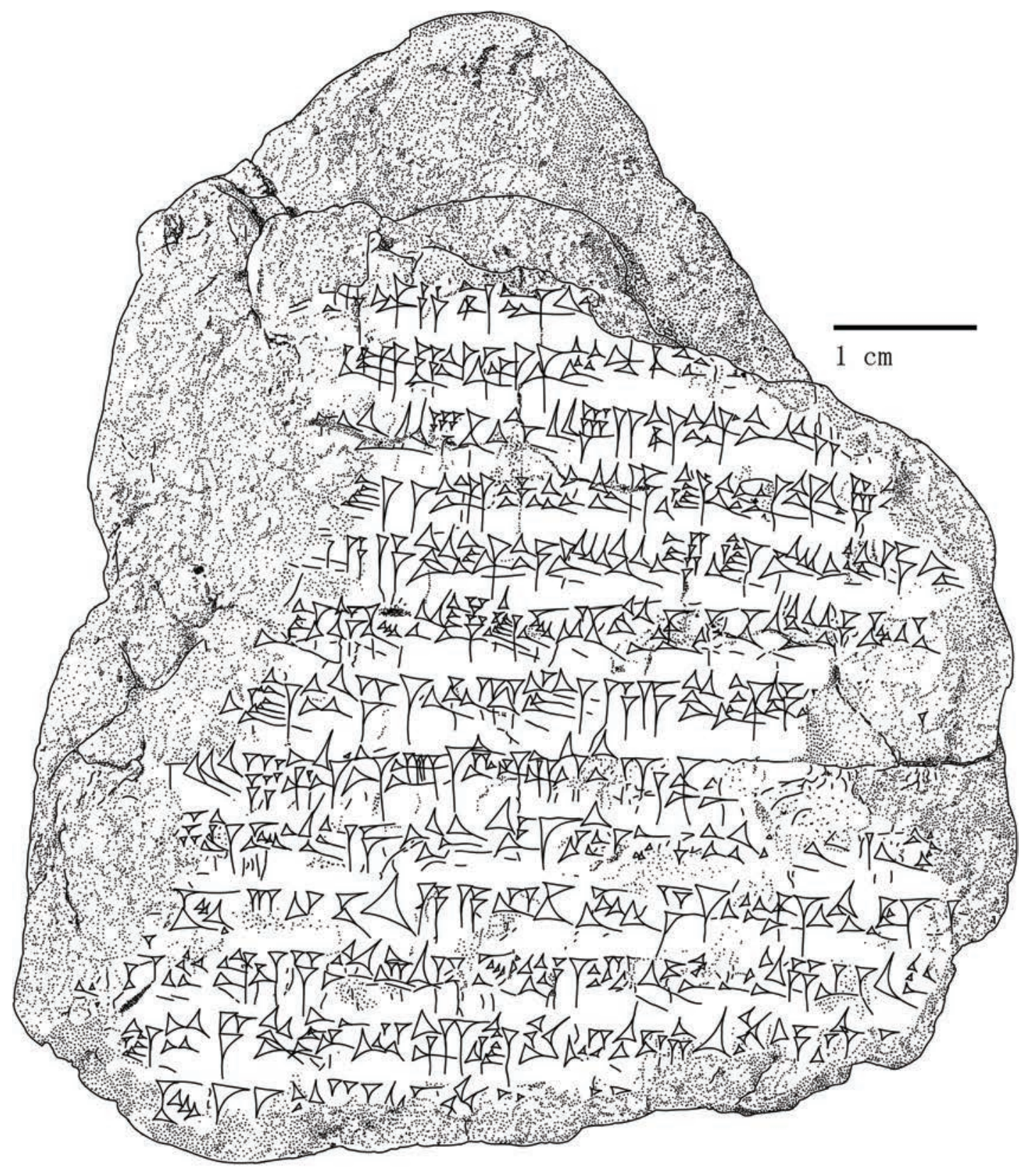

Fig. 1: BM 35183 'Obv.'?

(Photographed and traced by the author, courtesy of the Trustees of the British Museum) 